\title{
Sovereignty, Democracy, and Global Political Legitimacy
}

\section{Introduction}

Recent decades have witnessed burgeoning global political movements aimed at strengthening the political legitimacy of global institutions. This push for stronger political legitimacy - understood in normative terms as political 'support-worthiness' (Buchanan and Keohane 2006; Macdonald 2016) - has been motivated in part by commitment to many recognizably democratic values such as transparency, accountability, inclusion, representation, deliberation, and empowerment. Yet more direct talk of 'global democracy' still attracts strongly sceptical responses. Much of this scepticism stems from doubts about the feasibility of reconstructing familiar state-based democratic institutional models on a global scale (Dahl 1999; Grant and Keohane 2005; Miller 2010; Wendt 1999), as envisaged by 'cosmopolitan' (Held 1995; Archibugi 2008; Cabrera 2005) and 'transnationalist' (Macdonald 2008; Dryzek 2006; Bohman 2007) democratic theorists. In response, global democrats have advanced mostly empirical counter-arguments, aimed at expanding estimations of what may in fact be politically achievable (Koenig-Archibugi 2010; List and Koenig-Archibugi 2010).

In this chapter, I develop an alternative strategy for reconciling global democratic values with empirical facts about the structure and dynamics of contemporary global governance. Instead of disputing skeptics' empirical claims about real-world obstacles to cosmopolitan and transnationalist democratic institutional models, I challenge some implicit normative assumptions underlying their arguments. These assumptions concern the sources of political legitimacy within democratic institutions, and the range of realizable global institutional forms that should thereby count as democratic.

More specifically, I argue that the normative theories of democracy invoked in debates about global democracy construe the institutional ingredients of 
democracy's political legitimacy too narrowly: they focus on contributions to political legitimacy made by institutions of democratic social choice-making, such as elections and public deliberative structures, while neglecting those made by institutionalized governance capabilities, of the kind historically embodied in sovereign states. When problems of democratic institutional design arise within sovereign states, the narrow focus on democratic choice-making institutions matters little, since the availability of adequate material governance capacities can be taken for granted as a theoretical background condition. But this narrow focus becomes problematic when we are concerned instead with institutional design problems at the global level, where key governance functions of sovereign institutions are weak or absent. To understand the institutional pre-requisites for political legitimacy within a global democracy, I argue that we therefore need to build and apply a broader theoretical understanding of political legitimacy that can more systematically account for its governance capability dimensions. And when we do so, we are pointed towards revised institutional prescriptions for global democratization that conform much more closely to established sceptical assessments of what may be politically realizable.

In what follows I develop this argument in several steps, and explore its implications for our broader theoretical understandings of the relationships among sovereignty, democracy and global political legitimacy. In section one, I elaborate the distinction between the 'choice-making' and 'governance capability' dimensions of political legitimacy within democratic institutions. I further explain how democratic theories have evolved to focus too narrowly on the former, as a result of their historical preoccupation with the study of democratic states. In section two, I highlight some intuitive grounds for thinking that material governance capability in fact comprises a crucial substantive ingredient in the democratic legitimacy of global governance institutions, alongside democratic choice-making. In section three, I sketch the outline of a broader theoretical understanding of political legitimacy, which can better account for its governance capability dimensions in non-sovereign institutional contexts. In conclusion, I point to some implications of these theoretical 
arguments for global institutional design, and the realizability of projects of global democratization.

\section{Choice-making process versus governance capability as sources of political}

\section{legitimacy}

The idea of political legitimacy is central to the normative analysis of democratic institutions, insofar as the justifying purpose of democracy is widely understood to be that of legitimizing governance institutions. Here legitimacy is a standard of acceptability - that is to say, a standard denoting that an institution warrants support, without necessarily conforming perfectly to some moral ideal such as justice (Buchanan and Keohane 1996; Macdonald 2016). In much democratic theory the idea of political legitimacy sits in the background, with a focus instead on questions about what democracy is (in terms of competing conceptions or fundamental principles), or how it can best be institutionalized (in terms of competing institutional models). But underlying these conceptual and institutional arguments are claims about the democratic sources of political legitimacy: what it is about democratic institutions, in other words, that makes them warrant support. Arguments for or against competing conceptions or institutional models all need to refer back to substantive understandings about the sources of political legitimacy to ground their justificatory claims.

Theoretical arguments about the sources of political legitimacy in democratic institutions are complex and diverse, and I cannot survey them here. But for present purposes it is enough to highlight one feature that most share in common: they locate the sources of political legitimacy in processes of democratic social choice-making. By this, I mean those processes through which the content of collective political decisions is institutionally articulated - for instance, through elections or deliberative decision-making. Democratic theorists have identified sources of political legitimacy in a range of constitutive principles for social choice-making - typically focused on constituting choicemaking in a way that inclusively (Goodin 2007; Young 2002), equally (Barry 1991; Beitz 1989), and rationally (Knight and Johnson 1994; Benhabib 1994) reflects the shared political values of some democratic collective. These choice- 
making principles, in turn, articulate an interpretation of the broader political value of collective self-determination, which is central to the democratic project.

The problem with these social choice-focused democratic accounts of political legitimacy is that they cannot account for powerful intuitions that the political legitimacy of democratic institutions derives in part from the value of their functional governance capabilities. By this, I mean institutions' capabilities for supporting those forms of social coordination, control, and resource allocation that are required to advance materially the shared political values of democratic collectives. Such governance capabilities are pre-requisites for advancing a wide range of political values and goals - including those articulated within democratic social choice processes. As such, they are essential for any materially realizable democratic project of collective self-determination. Within democratic theory, however, the functional characteristics of such governance capabilities are not systematically analyzed as substantive ingredients in the constitution of political legitimacy. Rather, they are recognized as ingredients in political legitimacy only derivatively: either as instruments for implementing particular democratic choices after they have already been legitimately made; or as constituents in democratic choice-making, in the form of coercively-backed protections for practices of political inclusion, equality, and rationalized social choice.

The idea that material governance capabilities may be independent ingredients in normative political legitimacy resonates more strongly with some recent sociological theories, which differentiate 'output' and 'input' sources of political legitimacy (Scharpf 1999; 2003). Given the pervasiveness of this input/output distinction within current political analysis, it is worth briefly clarifying its relationship to the two dimensions of political legitimacy I am distinguishing here. The concepts of input and output legitimacy are deployed mostly in explanatory sociological analysis - to differentiate two types of evaluative judgment that motivate political support for institutions. But some theorists have argued that these judgment types map onto an underlying distinction between two sources of normative political legitimacy. In normative analysis, 
'input' legitimacy focuses on the value of those political processes - including, crucially, democratic choice-making processes - that feed in to and steer the activities of democratic institutions. 'Output' legitimacy, in contrast, focuses on the value of governance outcomes that institutions produce - or in other words, the 'common interests' or 'common goods' that they materially advance (Scharpf 1999, 2003; Steffek 2015).

At first glance, it may appear that my distinction between choice-making and governance capability dimensions of normative political legitimacy is equivalent to this familiar input/output distinction. Descriptively, democratic choicemaking processes do supply some substantive 'inputs' into the activities of democratic institutions; and normatively, these choice-making processes are often evaluated for substantive characteristics of this input (such as its structural inclusivity, equity, and rationality) rather than beneficial effects. Conversely, strong material governance capability is often descriptively correlated with (and can help to produce) valuable institutional 'outputs', and is commonly attributed normative value on this basis.

However, both choice-making and governance capability dimensions of democratic institutions can also be described and evaluated the other way around - viewing choice-making processes in output terms, and governance capability in input terms - if different normative criteria are applied. On the one hand, democratic choice-making processes can be viewed descriptively as outputs of wider institutional schemes - insofar as they have ongoing social preconditions that wider institutional schemes can either support or erode. And correspondingly, they can be evaluated in output terms for their wider political consequences - as they are in many instrumental arguments for and against democracy. On the other hand, institutions' governance capabilities can be descriptively viewed as 'inputs', insofar as they are constituted by ongoing contributions of resources, compliance, and other forms of material support from political agents. And in normative terms, it is not at all clear why we should assume that they are best evaluated in terms of the 'outputs' they produce, rather than (like democratic choice-making) in terms of the motivational inputs 
that drive these materially supportive actions. These in fact are precisely the kinds of normative questions I am raising here - and they are obscured, rather answered, by the question-begging application of the 'output' legitimacy label.

If these normative questions are not settled within established accounts of 'output' legitimacy, then, what could account for their theoretical neglect? That is, why have democratic theorists not developed more systematic normative arguments about whether and on what basis governance capability is a substantive ingredient of political legitimacy? My suggestion is that democratic theorists have neglected these questions because of their historical preoccupation with the study of democratic states. Historically, democratic theories have mostly assumed that governance capabilities are constituted in the form of state sovereignty - understood broadly as hierarchical rule-based political authority backed by control of force in a territory. Sometimes sovereignty is thought to be the appropriate governance framework for democratic politics on the basis that states have been the dominant form of political organization prompting democratic claims against them (Dewey 1927). Sometimes sovereignty is justified on strategic or moral grounds (or both) as the governance framework that democratic publics have strongest reasons to choose (Rawls 1996). But either way, the assumption of sovereignty as a theoretical background condition has enabled democrats to bracket normative questions about governance capabilities as exogenous to the democratic theory of political legitimacy.

Sovereignty and democracy have thus co-evolved as densely intertwined institutional models, nested together to form the overarching institutional systems of democratic states. The democratic theory of political legitimacy has maintained a focus on choice-making processes by assuming that they can simply be established as institutional 'add-ons' to sovereign governance structures that are independently justified in some acceptable way. We can say that theories of democratic legitimacy have evolved to piggy-back on justificatory arguments concerning state sovereignty, rather than explicitly incorporating 
their normative content as elements of their theory of political legitimacy. ${ }^{1}$ In the context of contemporary global politics, however, there is neither any operational global sovereign, nor any wide agreement on what an alternative justified framework of global governance institutions should look like. Under these circumstances, the democratic theory of legitimacy has no settled justificatory framework upon which to piggy-back, and must instead tackle normative questions about governance capabilities within the democratic theory of political legitimacy itself.

\section{Governance capability as an ingredient of global political legitimacy}

So far, I have argued that democratic theory has evolved without an adequate account of how the value of institutions' governance capabilities should be taken into account in assessment of their political legitimacy. But before we can consider how to account for this, it is first necessary to say more about why such an account is required. The normative case for recognizing valuable governance capabilities as substantive ingredients in political legitimacy can be appreciated most readily, I propose, by reflecting on intuitions about what political legitimacy requires in global institutions. This is illuminating because when theoretical analysis is focused on the institutional complex of the democratic state - in which democratic choice-making processes and state governance functions are operationally intertwined - it can be difficult to draw out clear intuitions about where exactly the political legitimacy is coming from. But when we instead examine global governance contexts in which these institutional elements are unbundled, some of the tensions and trade-offs between democratic choice-making and valuable governance capabilities are brought into clearer focus.

To draw out these intuitions, we can start by considering how global governance institutions differ from sovereign institutions with respect to their governance capabilities. Here we must first recognize the limited governance capabilities of sovereign institutions - which are centred on rule-making and enforcement

\footnotetext{
${ }^{1}$ For an influential discussion of the relationship between questions of state 'legitimacy' and 'justification' see Simmons (1999).
} 
capabilities. The functional specificity of states is sometimes obscured by traditional theoretical characterizations of sovereignty as 'absolute' or 'ultimate' power or authority within a territory, which imply openness with respect to the functions that sovereign institutions can perform. But this is misleading insofar as the state's hierarchical legal and bureaucratic authority, backed by its material capacities for force and coercion, comprise blunt regulatory tools. They can motivate only a limited range of behaviours, and correspondingly perform a limited range of functions. This recognition is backed by recent empirical literatures, which show how the functional capabilities of institutions vary with their distinctive mechanisms for achieving social coordination, control, and resource allocation (Rhodes 1996) - focusing in particular on differences between institutional hierarchies such as states, and the non-state institutional forms of markets and networks.

Growing appreciation for the diverse functional capabilities of non-state institutions has been influential in shaping the development of contemporary global governance institutions. In contrast to the coercive rule-enforcement functions of states, many global governance functions involve softer forms of collaborative political action - such as information creation and exchange, the promulgation of informal regulatory principles, and problem-solving around particular issue areas (Finkelstein 1995). To sustain these functions, many global institutions demand forms of actor autonomy, operational flexibility and agility, informational accumulation and exchange, and so on, which cannot be achieved optimally through hierarchical institutional structures alone. Meeting these demands requires a greater role for market and network mechanisms incorporating a range of non-state actors such as corporations and NonGovernmental Organizations (NGOs) alongside states and IOs (Cutler et al 1999).

Moreover, while some global governance functions are complementary, others conflict - since there is no universal agreement on what constitutes the global 'common interest' or 'common good'. As such, global governance institutions are organized around more local and partial agreements, arising from a complex web of interlocking and shifting transnational constituencies. Dense and 
dynamic interactions among these plural institutions then generate an overarching governance structure that can be described as 'complex' (Weiss and Wilkinson 2014) and in some aspects 'liquid' (Krisch 2017; Macdonald and Macdonald 2017) in character.

What, then, are the implications of these complex non-hierarchical institutional forms for political legitimacy in global governance? The crucial implication, I propose, is that they radically diminish the scope of the political control that democratic choice-making processes can exercise over governance activities. This loss of political control has two main sources. First, whereas political control within a hierarchical sovereign institutional structure is concentrated in a small number of sites of decision-making authority - typically legislatures, executives, and judiciaries - control is diffused within global governance institutions across a proliferation of diverse actors and institutional settings. This diffusion characterizes both the processes through which political actors express and coordinate values (for instance purchasing decisions in markets, or negotiations within networks), and the processes through which these values are converted into political outcomes through the operation of institutional power (for instance, through the pressures of material incentives and rewards channeled through markets, or those of the material interdependencies and forms of socialization that develop within networks). As a result of this diffusion, many institutions lack a clear institutional focal point or 'setting' for the exercise of political control, where established democratic decision-making principles of inclusion, equality, or rationality (in the form of rational preference aggregation or public deliberation) could be 'plugged in'.

Second, the political control that can be exercised through democratic choicemaking processes is further restricted by the more opaque character of the activities through which political values are expressed within complex nonhierarchical governance. Within a hierarchical sovereign institutional structure, political control is typically channelled through legal and bureaucratic processes, in which political values are clearly expressed through the explicit articulation and contestation of authoritative rules, directives, or principles. In contrast, the 
processes of control that drive functions within complex non-hierarchical global governance institutions embody more ambiguous expressions of political value.

For instance, the spending and investment activities that drive the functions of particular market institutions - such as economic 'supply chain' institutions (Macdonald 2014) - are often weaker indicators of actors' political values, insofar as they are routinely undertaken without access to adequate information about their wider political implications. Similarly, the incremental activities that shape the development of network relationships - to share or not share information and resources, to honour or renege on informally negotiated commitments, and so on - can be significantly shaped by local norms and accountabilities that develop within and sustain these relationships (Papadopoulos 2007), thus obscuring the wider political values that spurred network participation in the first place. When political values are expressed in these more opaque ways, the scope of democratic choice-making control diminishes insofar as it becomes unclear what activities should count as political 'choices', and thereby be subject to democratic choice-making principles of inclusivity, equality, and rationality.

Established arguments from cosmopolitan and transnationalist global democrats can offer some responses to these concerns. Cosmopolitans claim that such existing democratic legitimacy deficits necessitate developing hierarchical statelike governmental structures on a global scale, more amenable to control through democratic choice-making processes (Cabrera 2005). Transnationalists claim that political control through democratic choice-making can be restored within non-hierarchical governance structures through creative re-design of democratic choice-making mechanisms - such as flexible new forms of deliberative engagement (Dryzek 2006), non-electoral representation (Macdonald 2008), or participation (Warren 2002). Remaining political legitimacy deficits are then treated as concessions to a methodological 'realism', 
captured by the idea that complex global governance is an empirical fact to which democratic institutions and their justifications must respond. ${ }^{2}$

But these responses do not adequately account for the deep normative tensions and trade-offs that underlie choices among these institutional alternatives. In advocating the construction of sovereign-style global institutions, cosmopolitans fail to acknowledge the strong functional values that support existing nonhierarchical global governance structures. While there are certainly many drivers for the existing global governance structure - including the pressures of strategic power politics - one central driver is the widespread view that hierarchical governance is functionally ill-equipped to solve complex global problems. Transnationalists similarly advance few direct normative arguments in support of non-hierarchical global governance institutions, notwithstanding their willingness to adapt democratic choice-making institutions to their structural demands. By casting concessions to non-hierarchical institutional structures as responses to feasibility constraints, they downplay the extent to which they may in fact respond to normative demands for the discharge of valuable governance functions.

In sum, there are strong intuitive grounds for thinking that the functional value of governance capabilities should be accommodated, alongside the democratic character of choice-making processes, in overall assessments of political legitimacy. But established democratic theories of political legitimacy provide no clear account of the criteria by which the value of governance capabilities should be judged, in lieu of judgments expressed through democratic choice-making processes. As a result, they cannot explain how trade-offs should be made between an institution's valuable governance functions and its democratic choice-making controls, when their institutional demands conflict. The need for a normative account of this kind, then, raises an important challenge to which global democratic theorists must respond.

\footnotetext{
${ }^{2}$ Transnationalists' gestures towards political realism mirror those underlying a broader theoretical literature on democracy in non-hierarchical governance (Fung 2006; Sorensen and Torfing 2016).
} 


\section{Global political legitimacy in a post-sovereign era: a new research agenda}

Although established democratic theories incorporate no systematic account of the governance capability dimension of political legitimacy, broader theoretical traditions of liberalism, republicanism, realism, and pragmatism have said more about it. Often they have done so in arguing for sovereign institutions as a politically legitimate framework for democratic politics. ${ }^{3}$ But the problem with these arguments from a democratic perspective is that they all appeal to substantive values that are not globally shared. As such, appeal to these values as sources of political legitimacy cannot readily be reconciled with the central democratic value of collective self-determination.

Some liberals and republicans, first, have argued that political legitimacy requires special material governance capabilities that are functionally independent from democratic choice-making in order to protect some purported 'common interest' from capture by self-interested public officials or special interest groups. Often these capabilities are prescribed in the form of constitutional structures, institutionally insulated from direct control by democratic legislatures or executives. Typically the content of this 'common interest' - and thereby of political legitimacy more broadly - is given by the application of some principles of justice (Valentini 2012), or 'thinner' moral principles (Buchanan and Keohane 2006; Erman 2015), that are backed by philosophical justifications. But it is not clear how the institutionalization of such moral standards can be reconciled with the democratic value of collective selfdetermination within global populations among whom these standards are themselves matters of deep political disagreement.

Others have argued that political legitimacy requires special governance capabilities that are functionally independent from democratic choice-making to support political 'problem-solving' activities. Conceptions of political 'problems' vary, but include the problem of 'order' emphasized by theoretical 'realists' like Williams (2005), and problems understood in 'pragmatic experimentalist' terms

\footnotetext{
3 Broader arguments of this kind are surveyed by Scharpf (2003) in his analysis of 'output' legitimacy, though for reasons outlined earlier I do not invoke that language here.
} 
as targets of politically collaborative experimental inquiry and action (Sabel and Zeitlin 2008; De Burca, Keohane and Sabel 2014). This problem-solving approach provides more scope for achieving democratic political legitimacy under conditions of moral disagreement, and as such is suggestive and important. But normative criteria for diagnosing and solving global problems can also attract deep political contestation - albeit on different justificatory terms from moral disputes. Some authors invoke problem-solving standards of 'effectiveness' (Gutner and Thompson 2010), or broader epistemic standards (Steffek 2015), as alternatives to controversial moral principles. But instrumental and epistemic standards can only supplement - not substitute for thicker normative criteria specifying what kind of problem-solving strategies should be 'effectively' pursued. And it remains unclear how these criteria can be identified without appeal either to politically contested moral principles, or to democratic choice-making processes.

How then can democrats account for widespread intuitions about the importance of governance capability to political legitimacy, given these problems with established theoretical arguments? Here I propose another promising theoretical framework for this task, which identifies support for institutions' governance capability as one element of a normative conception of political legitimacy centred on advancing collective empowerment. The value of collective empowerment is closely related to that of collective self-determination. But whereas familiar democratic conceptions of self-determination are formulated as ideals of empowered collective choice-making, as discussed above, the conception I am proposing here is formulated as an ideal of empowered collective action more broadly conceived (Macdonald 2015, 2016; Macdonald and Macdonald 2017).

This shift in conceptualization helpfully accommodates the claim that shared political values - or 'common interests' - can be expressed in various political activities beyond democratic 'choice-making'. This claim is that political values are not always expressed communicatively - in the form of explicitly articulated normative 'principles' or 'conceptions', such as moral or problem-solving 
standards. Rather, they are often expressed behaviourally - through the patterns of value-responsive activity that constitute institutional 'practices'. The idea that social practices embody some non-propositional knowledge is already wellestablished (Taylor 1985); and some recent normative theorists have argued that political value judgement can be similiarly practice-based (Geuss 2009; Philp 2007). Value judgements can be regarded as practice-based insofar as they are produced in part through non-cognitive evaluative faculties such as attentional and emotional responsiveness, and politically expressed through conduct alongside communication.

Recognizing the practice-based constituents of political values can help us to move past the problems with established theoretical accounts of the governance capability dimension of political legitimacy, discussed above. It can do so by opening up a new avenue for analysis of 'common interests' in the absence of their articulation through formal communicative mechanisms such as public deliberation or voting. The basic idea is that institutional practices can embody shared political values expressed behaviourally by their participants through ongoing patterns of material support for institutions - even when participants do not agree, in cognitive or communicative terms, on substantive moral principles or problem-solving criteria for these institutions. When institutional participants lend support through their joint participation to the production and maintenance of some material set of institutional governance capabilities, they express at the very least shared value placed on these capabilities themselves even if different participants consider them worthy of support on the basis of competing strategic goals or moral principles. The content of the governance capabilities that should be regarded as ingredients in political legitimacy can then be identified theoretically through critical interpretation of institutional practice, as a supplement to agreements reached through democratic choicemaking processes.

To realize the potential of this theoretical account, more work must be done to develop it in both conceptual and institutional dimensions. First, democrats need to develop more robust practice-based conceptions of collective action and 
collective empowerment, able to generate methods of analysis for interpreting institutional practices, and discerning the ways and degrees to which they can be understood as expressive of non-cognitive value judgements as distinct from realpolitik political pressures. This can enable assessment of how non-choicedriven global governance practices - such as the market and network governance practices discussed earlier - reflect 'common interests' of the kind that can supply substantive standards of global political legitimacy in the governance capability dimension. More must also be said about how the boundaries of practices can be delineated within 'complex' and 'liquid' institutional contexts such as those in contemporary global politics. On both issues we may benefit from insights in practice-based critical and social theories of collective action (for instance: Joas 1996; Boltanski and Thevenou 2006), as well as new methodological work aimed at understanding how the normative principles that regulate institutions should depend on empirical features of underlying social practices (Williams 2005; Floyd 2016; Ronzoni 2009; Sangiovanni 2008; Williams and Warren 2014).

In addition, democrats need to develop new institutional principles and prescriptions for fostering political legitimacy understood as empowered collective action, tailored to diverse global governance contexts. At the centre of any new institutional agenda must be protections for political collaborations driven by practice-based - as well as formal choice-based - shared political judgements. More concretely, this may lend democratic support to a threepronged institutional programme: strengthened emphasis on institutionalized human rights protection, justified as core international instruments for broad political empowerment; renewed focus on institutionalizing material social and economic empowerments, alongside empowered social choice; and recognition of contextually variable standards of political legitimacy within global institutions, to accommodate the varying governance functions that achieve political support in practice in each institutional case. In developing this institutional agenda, democrats can build upon realist and republican ideas about the importance of institutionalized 'non-domination' in creating space for empowered political agency (Buckinx et al 2015; Pettit 2010), as well as wider 
bodies of work on political empowerment (Fung 2006) and global political legitimacy (Buchanan 2010).

It remains an open question whether this collective empowerment conception of global political legitimacy is best formulated as a straightforwardly 'democratic' theory, or in more conceptually freestanding terms. To accept it as democratic we would need to be conceptually flexible in how we formulate the democratic conceptions of political empowerment and equality, in particular. But by maintaining a focus on the empowerment of collective agency - rather than imposing moral or epistemic conceptions of the common good lacking global political acceptance - this way of thinking about the governance capability dimensions of global political legitimacy resonates more strongly with democratic ideals than other established alternatives. As such, it has the potential to help us better understand the democratic sources of political legitimacy in global governance contexts where institutional decision-making is structured in ways incompatible with traditional democratic choice-making principles.

\section{Conclusions}

I began this chapter with the question of how democrats should respond to the charge that democratizing global political institutions is utopian or infeasible, and I want to return to that question briefly in conclusion. Whereas the charge of utopianism generally presupposes state-like cosmopolitan institutional models to embody the global democratic 'ideal', to be assessed for feasibility, I have presented here an analysis of the democratic sources of political legitimacy that opposes this framing supposition. Instead, I have argued that many of the nonsovereign global governance institutions that democratic sceptics cite as obstacles to realizing global democracy may be better viewed as substantive ingredients in it, insofar as they contribute to the substantive functional value produced through global governance activity - as this is understood by the mix of global actors by and for whom they are constituted. At least to the extent that we see democratic institutional ideals as oriented towards achieving normative political legitimacy (as distinct from justice, or some other substantive moral or 
epistemic standard), there are thus good normative reasons for opening up familiar theoretical and institutional models of democracy for substantial revision.

This re-thinking of the relationship between democracy and political legitimacy also contributes new insights to longstanding theoretical debates about the democratic value of sovereignty as a central institution in international politics. Whereas democratic theorists have conventionally attributed value to sovereign institutions on the basis that they can provide the most hospitable institutional framework for mechanisms of democratic collective choice (Miller 2010), my arguments here suggest that sovereign institutions can also contribute more directly to democratic projects through the political legitimacy that their special governance capabilities can confer. A central challenge for democrats in the era of post-sovereign global governance, therefore, is to assess how the choice-making and governance capability dimensions of political legitimacy can best be weighed and reconciled, and on this basis to develop creative new institutional designs with greater sensitivity to these competing demands.

\section{References}

Archibugi, D. 2008. The Global Commonwealth of Citizens: Toward Cosmopolitan Democracy. Princeton: Princeton University Press.

Barry, B. 1991 'Is democracy special?' In Essays in Political Theory: Democracy and Power (Vol. 1). Oxford: Clarendon Press: 24-60.

Beitz, C. 1989 Political Equality: An Essay in Democratic Theory. Princeton: Princeton University Press.

Benhabib, S. 1994. Deliberative Rationality and Models of Democratic Legitimacy. Constellations, 1(1), 26-52.

Bohman, J. 2007. Democracy Across Borders. Cambridge, Mass.: MIT Press.

Boltanski L and Thévenot L. 2006. On Justification: Economies of Worth. Princeton University Press.

Buchanan, A. 2014. The heart of human rights. Oxford: Oxford University Press.

Buchanan, A. \& Keohane R. 2006. The legitimacy of global governance institutions. Ethics \& International Affairs 20(4): 405-437.

Buckinx, B., Trejo-Mathys, J. \& Waligore, T. (eds) 2015. Domination and Global Political Justice: Conceptual, Historical, and Institutional Perspectives, New York, Routledge.

Cabrera, L. 2005. Political Theory of Global Justice: A Cosmopolitan Case for the World State. London: Routledge.

Cutler, C., Haufler, V. \& Porter, T. 1999. Private authority and international affairs, SUNY series in global politics. Albany: State University of New York Press. 
Dahl, R. A. (1999). “Can international organizations be democratic? A skeptic's view", in Shapiro, I., \& Hacker-Cordon, C. Democracy's edges. Cambridge University Press: 19-36.

De Búrca, G., Keohane, R. \& Sabel, C. 2014. "Global Experimentalist Governance." British Journal of Political Science 44(3): 477-486.

Dewey, J. 1927 The Public and Its Problems. Denver: Allen Swallow.

Dryzek, J. 2006. Deliberative Global Politics: Discourse and Democracy in a Divided World. Cambridge: Polity.

Erman, E. 2015. “Global political legitimacy beyond justice and democracy?" International Theory. DOI: 10.1017/S1752971915000196

Finkelstein, L. S. 1995. What is global governance?. Global governance, 1(3), 367372.

Floyd, J. 2016. Normative behaviourism and global political principles. Journal of International Political Theory, 1755088216630998.

Fung, A. 2006. Varieties of participation in complex governance. Public administration review, 66(1), 66-75.

Geuss, R. 2009. 'What is political judgement?' In Bourke, R., and Geuss, R. (eds) Political Judgement: Essays for John Dunn. Cambridge: Cambridge University Press.

Goodin, R. 2007. 'Enfranchising all affected interests, and its alternatives'. Philosophy \& Public Affairs 35(1): 40-68.

Grant, R., and Keohane, R. 2005. "Accountability and Abuses of Power in World Politics." American Political Science Review 99(1).

Gutner, T., \& Thompson, A. 2010. The politics of IO performance: A framework. The review of international organizations, 5(3), 227-248.

Held, D. 1995. Democracy and the Global Order: From the Modern State to Cosmopolitan Governance. Stanford: Stanford University Press.

Joas H. 1996. The Creativity of Action. University of Chicago Press.

Knight, J., \& Johnson, J. 1994. Aggregation and deliberation: On the possibility of democratic legitimacy. Political theory, 22(2), 277-296.

Koenig-Archibugi, M. 2010. 'Is global democracy possible?' European Journal of International Relations 7(3): 519-542.

List, C., \& Koenig-Archibugi, M. 2010. Can there be a global demos?: an agencybased approach. Philosophy and Public Affairs, 38(1), 76-110.

Krisch, N. 2017 (forthcoming). 'Liquid authority in global governance'. International Theory.

Macdonald, K. 2014. The politics of global supply chains. Cambridge: Polity Press.

Macdonald, K. and Macdonald, T. (forthcoming 2017) 'Liquid Authority and Political Legitimacy in Transnational Governance', International Theory.

Macdonald T. 2016. Institutional facts and principles of global political legitimacy. Journal of International Political Theory 12(2): 134-151.

Macdonald, T. 2015. 'Political Legitimacy in International Border Governance Institutions', European Journal of Political Theory 14(4): 409-428.

Macdonald, T. 2008. Global Stakeholder Democracy: Power and Representation Beyond Liberal States. Oxford: Oxford University Press.

Miller, D. 2010. 'Against global democracy', In Breen, K. and O'Neill, S. After the Nation? Houndmills: Palgrave Macmillian: 141-160.

Papadopoulos, Y. (2007). Problems of democratic accountability in network and multilevel governance. European law journal, 13(4), 469-486. 
Pettit, P. 2010. "Legitimate International Institutions: A Neorepublican Perspective", in Besson, S., \& Tasioulas, J. (Eds.). The philosophy of international law. Oxford University Press.

Philp, M. 2007. Political Conduct. Cambridge, MA: Harvard University Press. Rawls J. 1996. Political liberalism. New York: Columbia University Press.

Rhodes, R. A. W. 1996. The new governance: governing without government. Political studies, 44(4), 652-667.

Ronzoni, M. 2009. The Global Order: A Case of Background Injustice? A PracticeDependent Account. Philosophy \& public affairs, 37(3), 229-256.

Sabel, C., and Zeitlin, J. 2008. "Learning from difference: the new architecture of experimentalist governance in the EU." European Law Journal 14 (3):271327.

Sangiovanni, A. 2008. Justice and the Priority of Politics to Morality. Journal of Political Philosophy 16(2): 137-164.

Scharpf, F. W. 2003. Problem-solving Effectiveness and Democratic Accountability in the EU (No. 03/1). Max Planck Institute for the Study of Societies.

Scharpf, F. W. 1999. Governing in Europe: effective and democratic?. Oxford: Oxford University Press.

Simmons, A. J. 1999. Justification and Legitimacy. Ethics, 109(4), 739-771.

Sørensen, E., \& Torfing, J. (Eds) 2007. Theories of democratic network governance. London: Palgrave.

Steffek, J. 2015. The output legitimacy of international organizations and the global public interest. International Theory, 7(2), 263-293.

Taylor, C. 1985. Philosophical papers: Volume 1, Human agency and language. Cambridge: Cambridge University Press.

Valentini, L. 2012. "Assessing the global order: justice, legitimacy, or political justice?" Critical Review of International Social and Political Philosophy 15(5): 593-612.

Warren, M. 2002. What can democratic participation mean today? Political theory, 30(5), 677-701.

Weiss, T. G., \& Wilkinson, R. 2014. Rethinking global governance? Complexity, authority, power, change. International Studies Quarterly, 58(1), 207-215.

Wendt, A. 1999. “A comment on Held's cosmopolitanism”, in Shapiro, I., \& Hacker-Cordon, C. Democracy's edges. Cambridge University Press: 1936.

Williams, Bernard. 2005. In the beginning was the deed: realism and moralism in political argument. Princeton: Princeton University Press.

Williams, M. \& Warren, M. 2014. 'A democratic case for comparative political theory'. Political Theory, 42(1), 26-57.

Young, I. M. 2002. Inclusion and democracy. Oxford: Oxford University Press. 


\section{University Library}

\section{- M M I N E R VA A gateway to Melbourne's research publications}

Minerva Access is the Institutional Repository of The University of Melbourne

Author/s:

MacDonald, T

Title:

Sovereignty, democracy, and global political legitimacy

Date:

2018-04-05

Citation:

MacDonald, T. (2018). Sovereignty, democracy, and global political legitimacy. Brown, C (Ed.). Eckersley, R (Ed.). The Oxford Handbook of International Political Theory, (1), pp.400-413. Oxford University Press.

Persistent Link:

http://hdl.handle.net/11343/292069 